\title{
Influence of selected climate parameters on tourist traffic of Kopaonik and Zlatibor mountains (Republic of Serbia)
}

\author{
Rastislav Stojsavljević ${ }^{*}$, Sanja BožićA, Milica KovačevićA , Milka Bubalo ŽivkovićA ${ }^{A}$ Đurđa MiljkovićA \\ Received: July 8, 2016 | Revised: October 13, 2016 | Accepted: December 14, 2016
}

\begin{abstract}
Tourism on Kopaonik and Zlatibor mountains had started to develop decades ago, but at the beginning of the 21st century, mountain tourism started to develop rapidly and the number of tourists in the mountain regions of Serbia has significantly increased. Constant improvements of tourism offer and numerous tourist activities on the Kopaonik and Zlatibor mountains influenced an upward trend of a number of tourists. The principal aim of this paper is to investigate whether the particular relevant climate parameters, such as mean monthly temperature and a number of snowy days, can affect the increase or decrease of the number of tourists and overnight stays in the analyzed two mountains. For this purpose, the regression analysis was used. The results indicate that there is a significant impact of selected climate parameters on tourist traffic in the Kopaonik and Zlatibor mountains.
\end{abstract}

Keywords: Kopaonik, Zlatibor, climate, tourism, regression analysis

\section{Introduction}

Climate itself can be a factor in attracting tourists, with favorable climate conditions being an important prerequisite for investments in tourism (Šabić, et al., 2012). Also, the length and quality of tourist season are often affected by local climatic factors (Scott, et al., 2004; Belen Gomez, 2005). This is why studying the relationship between climate parameters and tourist traffic is of paramount importance for the travel industry. Understanding local climate conditions is also important in various phases of tourism development: planning the hotel location, an organization of events, development of infrastructure, but also for maintaining the sustainable number of tourist in various part of the year. Many papers indicate that climatic characteristics of destinations, but also climate change can have a major influence on tourist flows (Gössling, et al., 2006; Hein, et al., 2009; Giannakopoulos, et al., 2011; Dinca, et al., 2014; León, Araña, 2016). Accord- ing to IPCC (Intergovernmental Panel on Climate Change, 2013) and its AR5 (Fifth Assessment Report), global surface temperature change for the end of the 21st century is likely to exceed $1.5^{\circ} \mathrm{C}$ for all scenarios. Also, it is likely to exceed $2^{\circ} \mathrm{C}$ for two scenarios. All of this indicates that tourism is largely dependent on climate and its effect can't be ignored.

Generally, it is agreed that "climate is a natural tourism resource and it is an element that, thanks to human intervention, facilitates tourism and the satisfaction of demand" (Gómez Martín, 2005). In addition, the coherence of climate and tourism activities has led to a development of a new branch of climatology, tourism climatology (Basarin, et al., 2014). This discipline is based on applied climatology and human biometeorology (Freitas, 2003; Matzarakis, 2006).

Climate factors in mountain tourism influence the tourist flows both in summer and winter months through specific parameters and elements. As moun-

\footnotetext{
A University in Novi Sad, Faculty of Sciences, Department of Geography, Tourism and Hotel management

* Corresponding author: Rastislav Stojsavlejvić, e-mail: rastislav.stojsavljevic@dgt.uns.ac.rs
} 
tain tourism is strongly dependent on natural and cultural resources, it is also especially dependent on climate conditions, which significantly affect tourism development in mountain areas. These areas are also considered amongst the most threatened ecosystems by climate changes (Elsasser, Messerli, 2001).

When it comes to Serbia, and its most visited mountain centers Kopaonik and Zlatibor, majority of scientific papers are dealing with tourist traffic with an emphasize on comparing tourist arrivals and overnight stays with other mountain centers, both domestic and foreign. If we analyze scientific papers in climatology filed, it is important to mention that Vujević (1961) was one of the first researchers who investigating bioclimatology of Kopaonik region. Bursać (1991) induced natural conditions for agricultural and forestry development in the wider area of Kopaonik mountain. Stanković and Ćirković (2002) showed certain characteristics of tourist traffic on Zlatibor, while Marković (2008) was investigating some aspects of hunting tourism on Zlatibor mountain. Ducić and Radovanović (2005) investigated climate characteristics of these two mountains in the book "Climate of Serbia". In terms of physical-geographical research Đurović and Menković (2008) studied the piracy of the Duboka River on the eastern slopes of Kopaonik. Kadović et al. (2009) explored types of soils in Kopaonik, while Pavlović and Jovanović (2009) studied some aspects of eco- and ethno-tourism on Zlatibor. Tourism of Zlatibor was also a topic of research by Plavša et al. (2009), and Ivanović (2007), while evaluation of tourist events was made by Romelić et al. (2009). Some aspects of tourism on Kopaonik were analyzed by Bojović and Plavša (2010; 2011) and Jovičić (1992), while Bučić et al., (2015) explored the possibilities for congress tourism development on Zlatibor mountain. Moreover, Živanović (2015) studied climate influences on forest fires on examples of Kopaonik and Zlatibor mountains. Based on the overview of previous research, it is evident that there were no studies exploring the relationship between climate factors and tourism traffic at the analyzed territory (Kopaonik and Zlatibor mountains).

However, there are some similar studies in the region, which are related to this research. For instance, Joksimović et al. (2013) used Tourism climatic index (TCI) as a bioclimatic indicator, developed by Mieczkowski (1985) to determine the impact of climate on the physical comfort of tourists. However, the value of TCI, as also stated by Joksimović et al. (2013), does not include the qualitative characteristics of rainfall for the needs of winter recreation tourism. In their paper, the climate conditions during winter months in Žabljak and Kolašin were ranked as undesirable. However, the fact that winter months are suitable for winter tourism, were neglected. As the study areas of the current re- search are mountain centers known especially for winter tourism, the use of TCI was considered inadequate. Instead, the regression analysis was used to examine the effects of climate on tourism flows.

On contrary, the use of this index has shown satisfactory results when applied to different type of tourist sites, such in the study of Basarin et al. (2014). In their paper, the data covering the period from 1949 to 2012 for two meteorological stations, Sombor and Zrenjanin was used to compute the Tourism Climate Index (TCI) for two special nature reserves in Vojvodina, North Serbia, "Gornje Podunavlje" near Sombor and "Carska bara" near Zrenjanin.

Furthermore, Surugiu et al. (2010, 2011) analyzed the relation between climate variability and tourism activity in Predeal resort, one of the most representative ski destination in Romania, showing that tourism activity is largely dependent on meteorological parameters (temperature and snow -cover depth). Their study shows the existence of a negative relationship between temperatures and tourism, which means that an increase in air temperature will generate a decrease in tourism parameters.

Also, Dinca et al. (2014) studied the stakeholder perspective on the effects of climate change for tourism activities in Vatra Dornei complex (spa and mountain resort in the northern part of Romanian Carpathians). In this paper, the authors also emphasize that this destination depends on to a great extent on climate resources which show a clear variability of main parameters on which its outdoor activities are based.

Due to the lack of similar research in mountain regions of Serbia, the main goal of this study is to investigate how chosen climate parameters (monthly mean temperatures and number of snowy days) affect tourist traffic in the most attractive mountains in Serbia Kopaonik and Zlatibor. It is important to note that tourist traffic in this paper is expressed by a number of tourist and their overnight stays (both domestic and foreign).

\section{Geographic position of the study area}

Kopaonik is the largest mountain range of Serbia that extends from the northwest to the southeast with the length of about $75 \mathrm{~km}$, while the maximum width reaches $40 \mathrm{~km}$ in its central part. Kopaonik Mountain is located between Ibar and Sitnica rivers in the west and southwest, Lab and Toplica in the south and east and Jošanica and medium flow of Rasina at the north. At the northwest, Kopaonik continues in Željin, Goč and Stolovi. The total area of this region is about 2.750 $\mathrm{km}^{2}$ (Bursać, 1991). Kopaonik has a good geographical position. The Ibar magisterial road passes through Kopaonik, and this mountain is also connected with the roads to the valley of the South Morava. Distance 


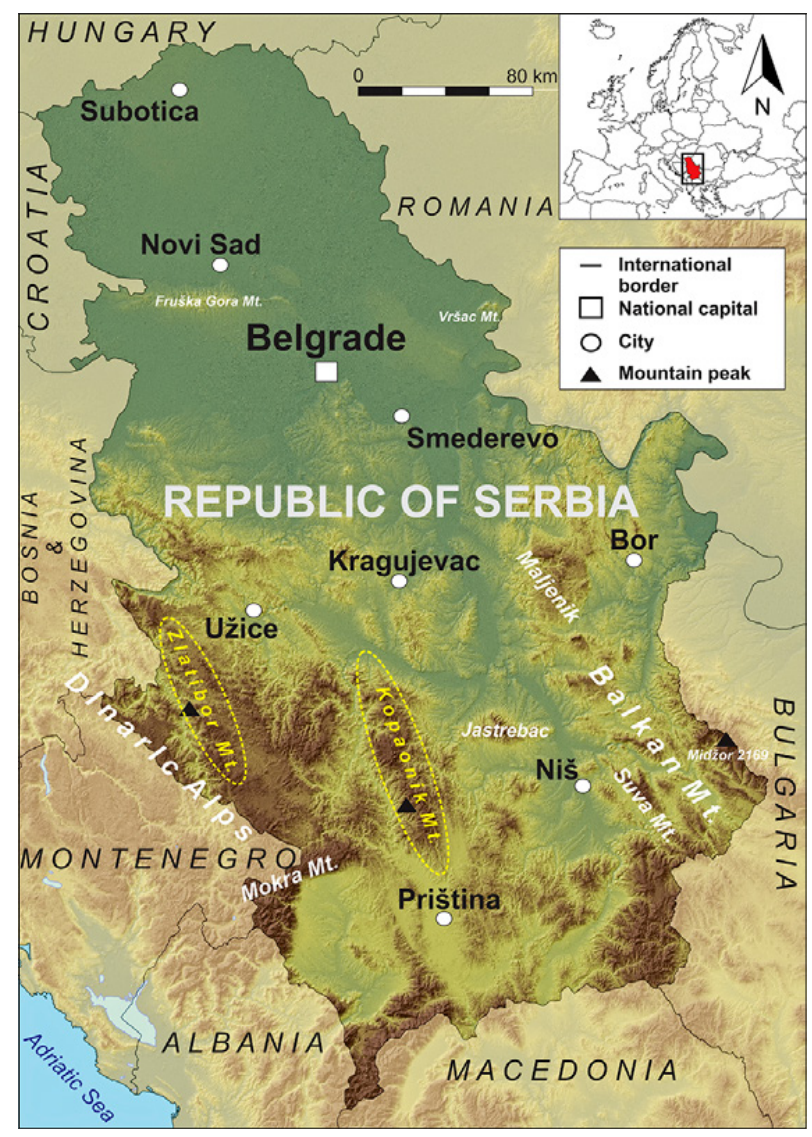

Map 1. Geographic position of Kopaonik and Zlatibor

from Kopaonik to Belgrade is about $280 \mathrm{~km}$ and about $190 \mathrm{~km}$ from Zlatibor. National Park Kopaonik covers an area in the northern part of the mountain that represents a spacious Ravni Kopaonik plateau.

Mountain Zlatibor is located in southwestern Serbia. It has Dinara's direction of spreading, i.e. northwest to southeast, with the length of $55 \mathrm{~km}$, the width of $22 \mathrm{~km}$, and a surface of $1.015 \mathrm{~km}^{2}$ (Jovanović, et al., 2015). It covers large parts of the widespread plateau of Starovlaška. It is spatial bordered on the northwest Kremna valley, in the north of the valley of the river Sušica and Mačkatska surface, in the southeast of the mountain Murtenica and south river Uvac. A foothill that represents the transition to Tara also belongs to Zlatibor. It is distanced $230 \mathrm{~km}$ from the capital of Serbia and passes through Zlatibor magisterial road that leads from Belgrade to the coast of Adriatic Sea. In the aspect of tourism, term Zlatibor implies to his central part, spacious rolling plateau, about $30 \mathrm{~km}$ long and 12 $\mathrm{km}$ wide, bordered by peaks and tops: Tornik, Čigota, Gradina, Čavlovac, Viogor, Crni vrh and the upper stream of the river Sušica (Đurić, Pavlović, 2005).

\section{The database and methodology}

The data used to create a database of temperature and precipitation values, for the purpose of this paper, were taken from meteorological statistical yearbooks of Republican Hydrometeorological Service of the Zlatibor and Kopaonik weather stations for the climatological period 2001 - 2014. The climate parameters that were used in this study are the mean monthly temperature and number of snowy days. The data about tourist traffic during the same period were obtained from the statistical yearbooks of Statistical Office of the Republic of Serbia (arrivals and overnight stays - total, domestic and foreign). The main statistical method used is regression analysis. In statistical modeling, regression analysis is a statistical process for assessing the relationships between variables. The main objective is to assess the relationship between a dependent and one or more independent variables. Regression analysis shows how much the dependent variable can be changed if changing one of the independent variables in order that remains unchanged (Wilks, 2006; Armstrong, 2012). This is just one of the methods which is used to obtain a formula that determines the difference between climate and statistical series (Stojsavljević, et al., 2013).

\section{Results and discussion}

The following chapter describes the impact of a number of snowy days and the mean monthly temperature on the tourist traffic in Kopaonik and Zlatibor mountains, as well as the comparative analysis of these two mountains.

\section{Tourist traffic of Kopaonik}

Tourist traffic of Kopaonik has significantly changed in the last 15 years. Figure 1 shows a declining trend in a number of overnight stays of both domestic and foreign tourists. That number has declined from 510.562 in 2002 to 233.912 overnight stays in 2010. After that, there has been an increase of numbers of overnight stays, although from 2013 there is again an evident decrease. The trend of overnight stays of domestic tourists is similar as previously explained. It can be seen that the trend line of foreign tourists shows a gradual increase with minor fluctuations in observed period. The largest number of foreign tourists stays overnights in Kopaonik in $2013-67.553$.

Figure 2 shows a drastic decrease in a number of total overnight stays in winter months compared to the rest of the year. That number has decreased from 75.000 in January to 9.000 overnight stays in November. The almost identical trend can be seen in the case of domestic tourists, with a slightly lower number of overnight stays in winter and summer months. In the observed period, the number of foreign tourists at Kopaonik is negligible. In April, October and November less than 300 foreign tourist overnight stays (on average) are recorded. 

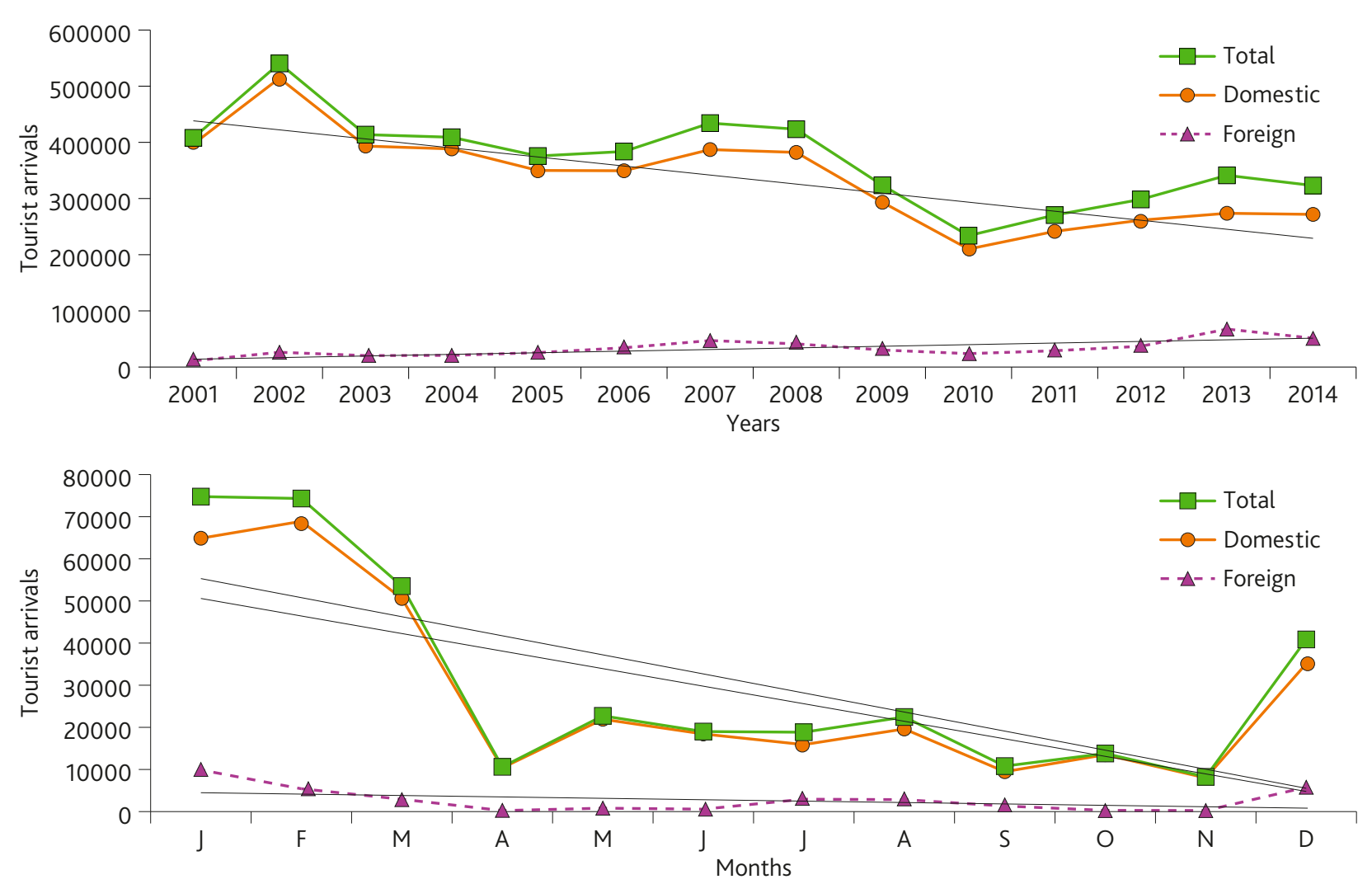

Figures 1 and 2. Overnight stays of tourist at Kopaonik by years and months for 2001-2014 period Source: Republican Statistical Bureau

In the period from 2001 to 2014 , there is a decreasing trend of a number of tourists (Figure 3). The largest number of tourist visited Kopaonik in $2002-123.514$, while the lowest number was in $2010-57.900$. The number of domestic tourists shows a similar trend. Although a number of foreign tourists gradually increases, their share in total number is still rather low.

Figure 4 shows evidently that the largest number of tourist visit in Kopaonik during winter months. At multi-year bases, the largest number of domestic visits is recorded during February - 12.262 and the smallest during November -2.033 . Foreign tourists mostly visit this mountain during winter. Trend lines of both foreign and domestic tourists show a decrease, but especially when it comes to domestic tourists. A number of average overnight stays per tourist largely decreased at Zlatibor (Figure 5), from maximum 5.8 in 2001 to minimum 3.8 in 2014 . On the other hand, at Kopaonik is recorded maximum 5.9 in 2005 and minimum 4 in 2001. Unlike Zlatibor, trend line on Kopaonik is in a slight decrease.

\section{Tourist traffic of Zlatibor}

If we look at the trend line on Figure 5, an increase in the number of tourists can be observed in period 2001 - 2014. The lowest number of tourists visited Zlatibor in $2003-70.877$, while the largest number of tourists was in $2011-116.302$. While the number of domestic tourists in that period was alternately increasing and decreasing, a number of foreign tourists was in continuing growth. Decreasing numbers of domestic and foreign tourists were recorded in 2009.

The number of tourist arrivals in Zlatibor has gradually decreased from January to December (Figure 6). If we look perennial average for the 2011-2014 period, the lowest number of tourist was recorded in November -4.811 , although a low number of tourist was also recorded in March and December. The largest number of tourists on this mountain arrives in May - average is 8.882. The lowest number of foreign tourist are in February - only 468. The largest number of tourist from abroad is during summer months, especially during August - average is 2.044. This can be explained by the fact that Zlatibor is mountain popular for day trips and excursions, and that ski tourism is not the primary form of tourism.

The number of tourists who stay overnight in Zlatibor has been rising in the past 14 years. There is a stronger trend of growth of foreign compared to domestic visitors. If we look at Figure 7, it can be seen that there is a lower number of overnight stays in 2003 than in 2001. The difference between these two years is more than 120.000 overnight stays. The largest number of overnight stays was in $2011-475.300$, while the smallest number was in mentioned $2003-$ 330.687. The situation is similar when we look at do- 

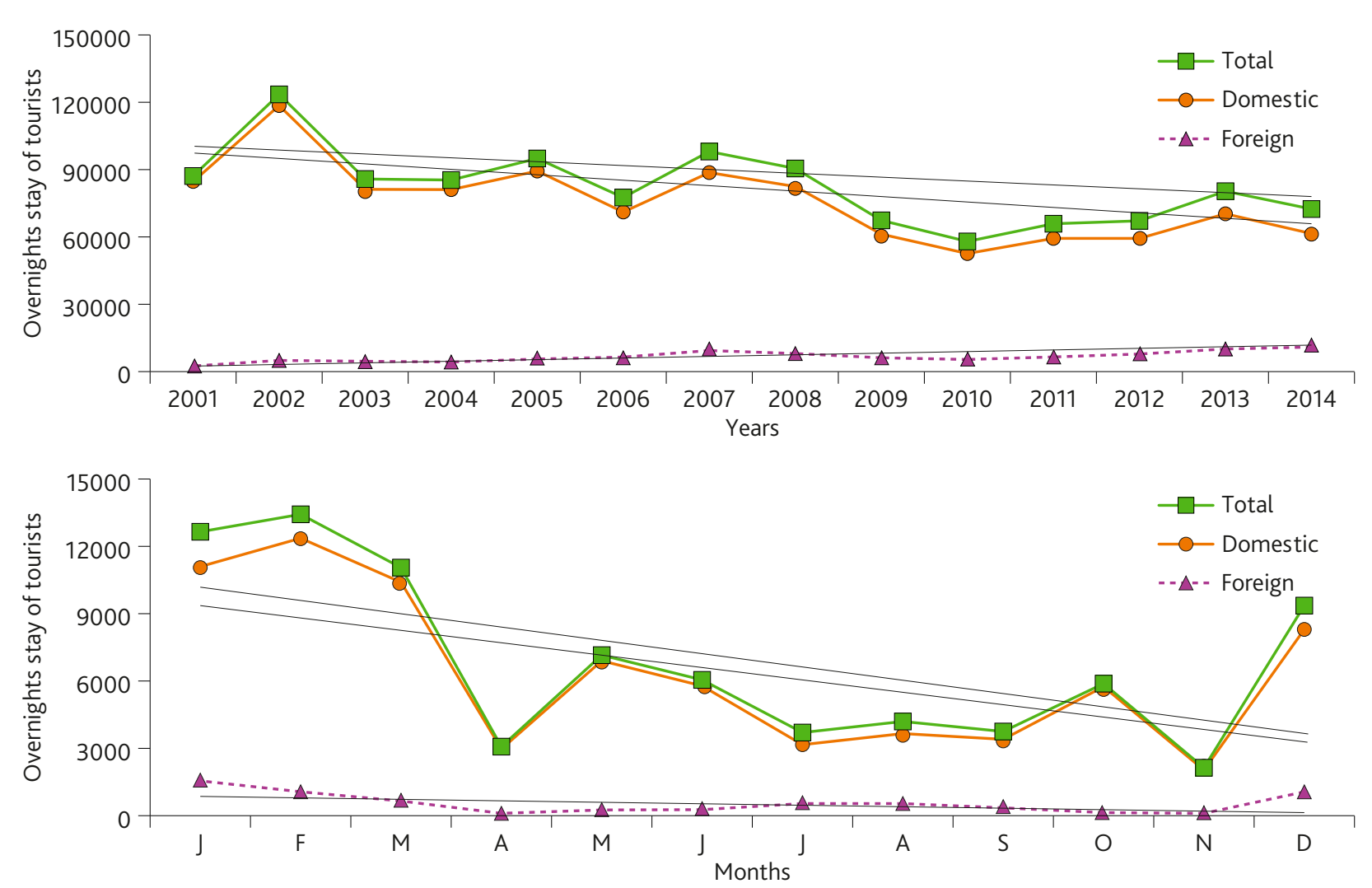

Figures 3 and 4. Tourist arrivals at Kopaonik by years and months for 2001-2014 period Source: Republican Statistical Bureau
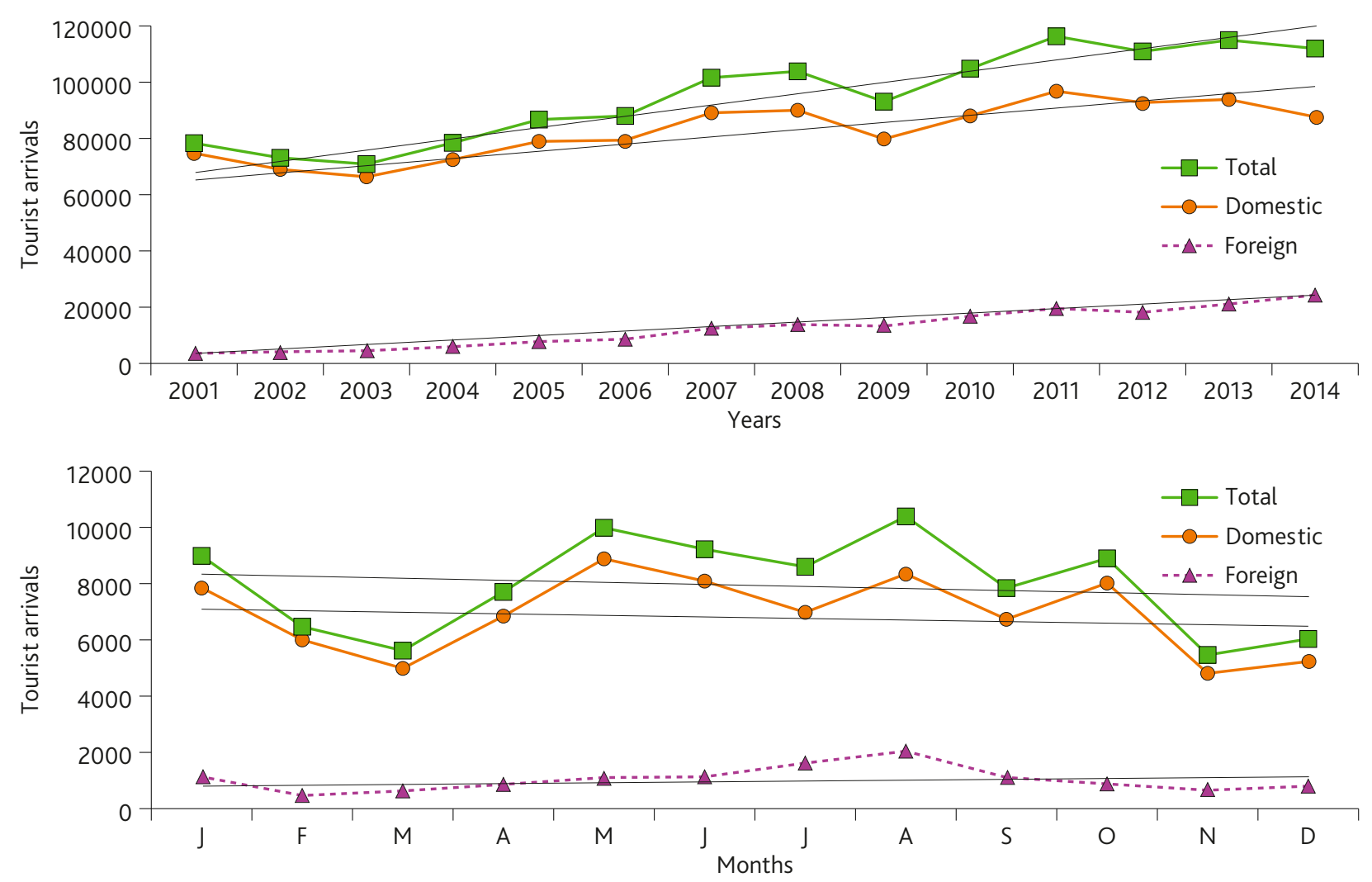

Figures 5 and 6. Tourist arrivals in Zlatibor by years and months for 2001-2014 period Source: Republican Statistical Bureau 

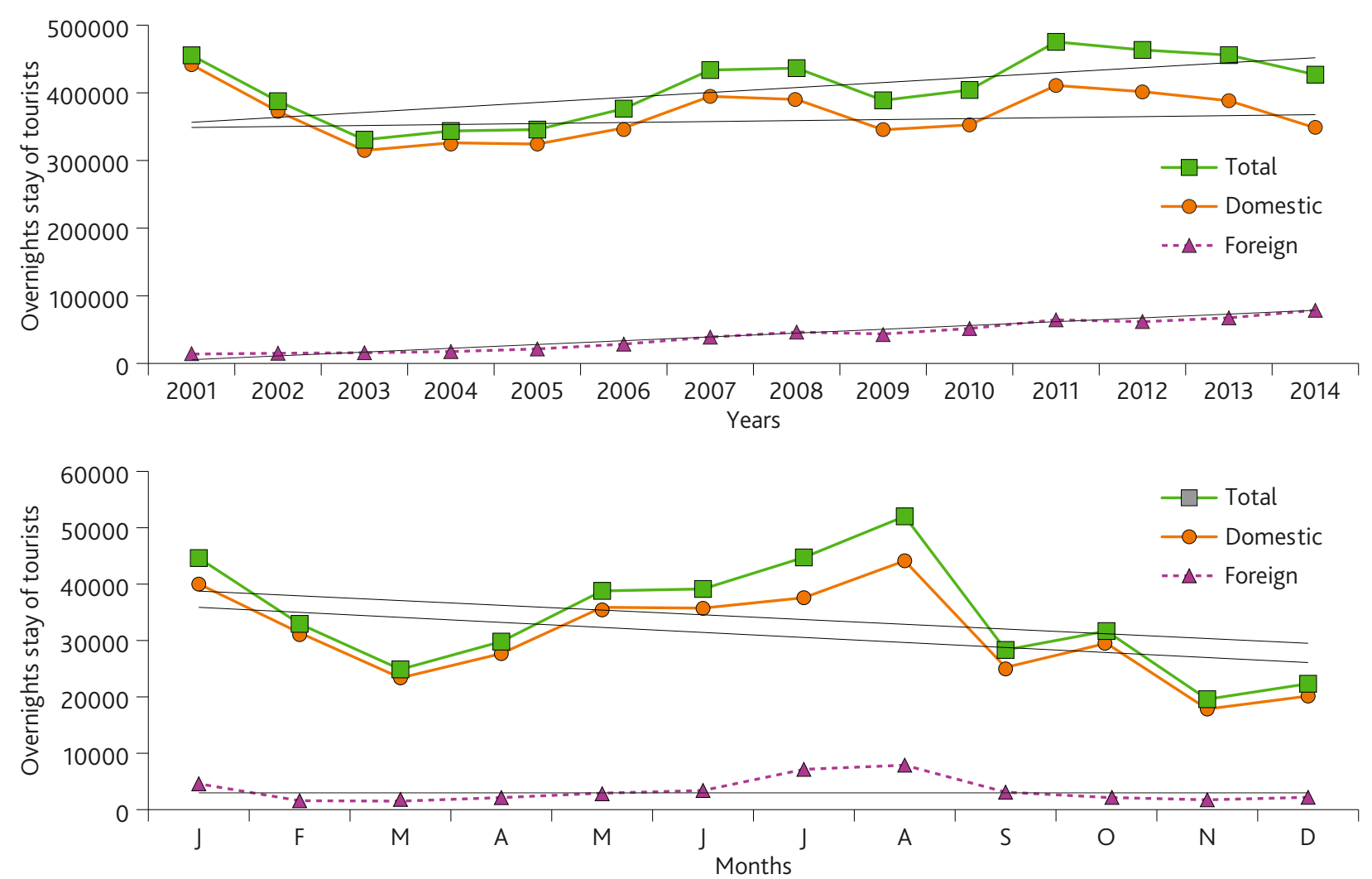

Figures 7 and 8. Overnight stays of tourist at Zlatibor by years and months for 2001-2014 period Source: Republican Statistical Bureau

mestic tourist overnight stays, as the largest number was in $2001-441.597$. The number of foreign tourists who stay overnight at Zlatibor has been increasing and the trend line is in constant rising from the beginning of the observed period. The largest number of foreign tourists' overnight stays was recorded in $2014-78.578$.

The trend of overnight stays decreases from January to December (Figure 8). According to Figure 8, the largest number is in August - 42.021, while the smallest number is in March - 19.586. The number of overnight stays of domestic tourists is the largest in January and the smallest in November. The trend of foreign tourists 'overnight stays is stagnant and this number is still relatively low. The largest number of overnight stays of foreign tourists is in July and August, and it is over 7.000. This can be explained that Zlatibor is a mountain popular for recreation for those who want to spend their summer vacations on the mountain.

\section{A comparison between the number of overnight stays by tourist at Kopaonik and Zlatibor}

Figures 9 and 10, show that the most overnight stays per tourist in Zlatibor are recorded in July - 5.2. The lowest numbers, however, are recorded during autumn. On contrary, the situation is different at Kopaonik. Average overnight stays per tourist were almost six in January, while the lowest number was in October - 2.3. 

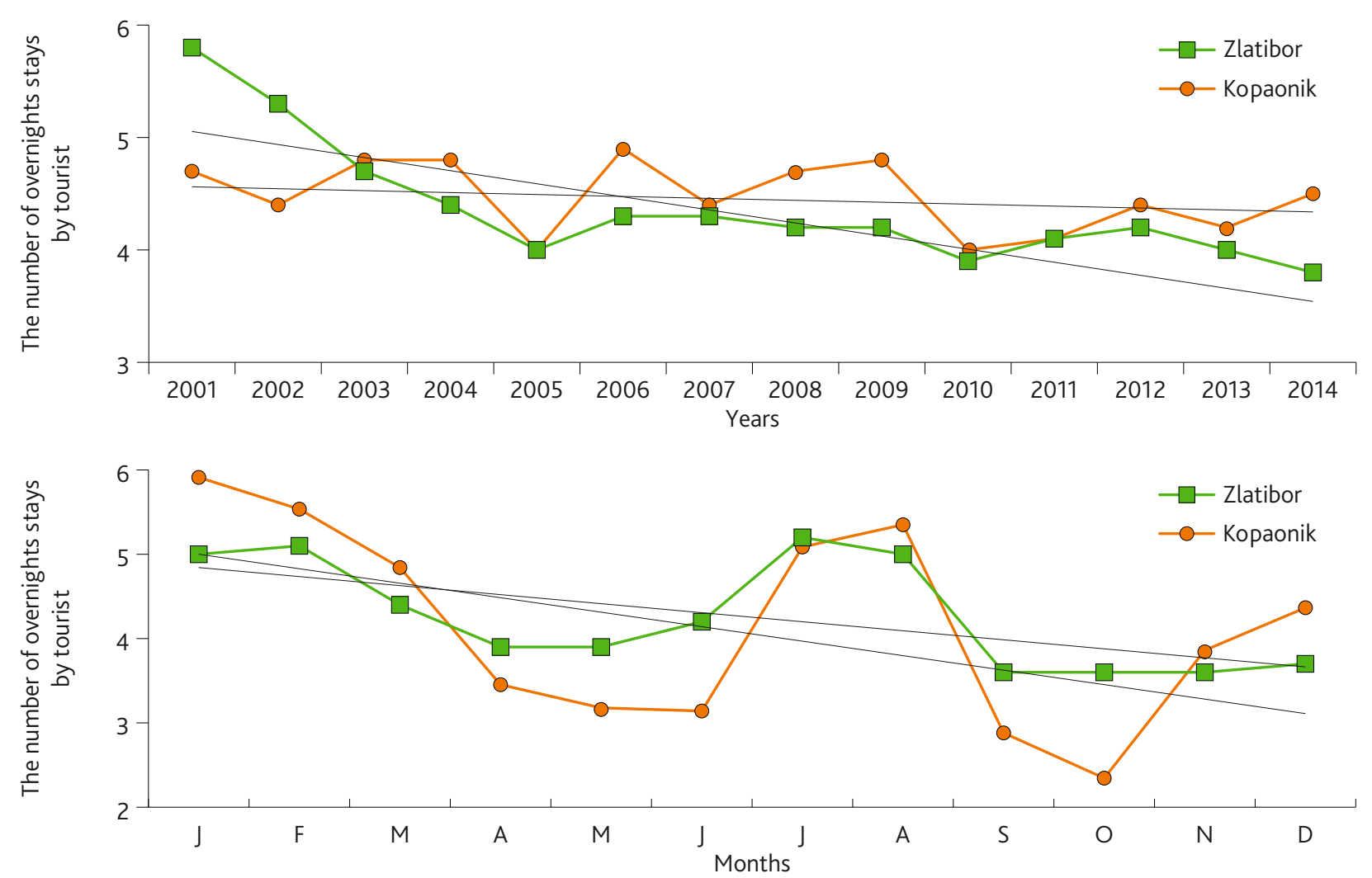

Figures 9 and 10. A comparison of the number of overnight stays by tourist by years and months at Kopaonik and Zlatibor for 2001-2014 period

Source: Republican Statistical Bureau

\section{Analysis of the impact of the number of snowy days on the tourist traffic at Kopaonik}

The regression analysis has been conducted, with an aim to determine if there is an influence of a number of snowy days on the tourist traffic on Kopaonik. Results indicate that the number of snowy days has a statistically significant impact of on the tourist traffic on Kopaonik. However, this can be applied only on specific months of the years (Table 1): in January, the number of snowy days has a negative influence on the total and the number of domestic tourists. This is also the case with the total and the number of domestic overnight stays. On the first glance, it seems like illogical finding. However, if we consider that Kopaonik Mountain is already acknowledged mountain in ski tourism, with January being the pick of the tourist season, it is reasonable that the number of snowy days does not influence tourist traffic. The fact that the most of the travel arrangements for this mountain are sold long before the winter season, can also support this finding. On contrary, there is no the significant influence of the number of snowy days on the number of foreign tourists and their overnight stays.

In March, there is a positive influence of the number of snowy days in case of the number of domestic tourists. This can be beneficial for domestic tourism, due to a positive impact on the extension of the tourist season. The foreign tourists, however, visit this mountain during the winter tourist season (from November to March). Furthermore, in April, there is a similar situation as in March, as there is a positive influence of snowy days on the total overnight stays and domestic overnight stays. From this, it can be concluded that the higher number of snowy days influences the extension of tourist season, especially in April and March, as it influences the higher number of domestic tourists and their overnight stays.

\section{Analysis of the influence of the mean monthly temperature on the tourist traffic on Kopaonik}

The results of the regression analysis indicate the significant negative impact of temperature on the total number of tourists in August, but also on the number of domestic tourists and their overnight stays in March. This result implies that lower temperatures in August on the mountain than on lower hills have a positive impact on the increase in tourist arrivals during the summer. Therefore, tourists seek escape from the summer heat on the mountain. The climatic factor (the mean monthly temperature) proved to influence the extension of the tourism season. In March, it is observed that there are negative regression coefficients: the lower temperatures affect the higher number of domestic tourists, which extends the tourist 
Table 1. Results of regression analysis - influence of the number of snowy days on the tourist traffic on Kopaonik

\begin{tabular}{|c|c|c|c|c|c|c|c|c|c|c|}
\hline \multirow{2}{*}{ Month } & \multirow{2}{*}{\multicolumn{2}{|c|}{ Model }} & \multirow{2}{*}{$\begin{array}{l}\text { Depeent } \\
\text { Variable }\end{array}$} & \multicolumn{2}{|c|}{$\begin{array}{l}\text { Unstandardized } \\
\text { Coefficients }\end{array}$} & \multirow{2}{*}{$\begin{array}{c}\text { Standardized } \\
\text { Coefficients } \\
\text { Beta }\end{array}$} & \multirow{2}{*}{$t$} & \multirow{2}{*}{ Sig. } & \multicolumn{2}{|c|}{$\begin{array}{l}95.0 \% \text { Confidence } \\
\text { Interval for B }\end{array}$} \\
\hline & & & & B & Std. Error & & & & $\begin{array}{l}\text { Lower } \\
\text { Bound }\end{array}$ & $\begin{array}{l}\text { Upper } \\
\text { Bound }\end{array}$ \\
\hline \multirow[b]{2}{*}{ January } & \multirow[b]{2}{*}{1} & (Constant) & \multirow{2}{*}{$\begin{array}{l}\text { The total } \\
\text { overnight } \\
\text { stays }\end{array}$} & 110152.374 & 12541.947 & & 8.783 & .000 & 82825.820 & 137478.9 \\
\hline & & $\begin{array}{l}\text { The number of } \\
\text { snowy days }\end{array}$ & & -2072.419 & 704.029 & -.648 & -2.944 & .012 & -3606.368 & -538.471 \\
\hline \multirow[b]{2}{*}{ April } & \multirow[b]{2}{*}{1} & (Constant) & \multirow{2}{*}{$\begin{array}{l}\text { The total } \\
\text { overnight } \\
\text { stays }\end{array}$} & 1936.901 & 3086.203 & & .628 & .542 & -4787.356 & 8661.159 \\
\hline & & $\begin{array}{l}\text { The number of } \\
\text { snowy days }\end{array}$ & & 894.113 & 298.354 & .654 & 2.997 & .011 & 244.055 & 1544.172 \\
\hline \multirow{2}{*}{ January } & \multirow{2}{*}{1} & (Constant) & \multirow{2}{*}{$\begin{array}{l}\text { The number } \\
\text { of domestic } \\
\text { tourists }\end{array}$} & 102074.098 & 11026.939 & & 9.257 & .000 & 78048.462 & 126099.7 \\
\hline & & $\begin{array}{l}\text { The number of } \\
\text { snowy days }\end{array}$ & & -2178.374 & 618.986 & -.713 & -3.519 & .004 & -3527.029 & -829.719 \\
\hline \multirow{2}{*}{ April } & \multirow[b]{2}{*}{1} & (Constant) & \multirow{2}{*}{$\begin{array}{l}\text { The number } \\
\text { of domestic } \\
\text { tourists }\end{array}$} & 1628.136 & 3066.757 & & .531 & .605 & -5053.754 & 8310.025 \\
\hline & & $\begin{array}{l}\text { The number of } \\
\text { snowy days }\end{array}$ & & 901.221 & 296.475 & .660 & 3.040 & .010 & 255.259 & 1547.184 \\
\hline \multirow{2}{*}{ January } & \multirow[b]{2}{*}{1} & (Constant) & \multirow{2}{*}{$\begin{array}{l}\text { The total } \\
\text { number of } \\
\text { tourists }\end{array}$} & 17983.242 & 2585.511 & & 6.955 & .000 & 12349.898 & 23616.586 \\
\hline & & $\begin{array}{l}\text { The number of } \\
\text { snowy days }\end{array}$ & & -312.495 & 145.135 & -.528 & -2.153 & .052 & -628.717 & 3.727 \\
\hline \multirow{2}{*}{ June } & \multirow{2}{*}{1} & (Constant) & \multirow{2}{*}{$\begin{array}{l}\text { The total } \\
\text { number of } \\
\text { tourists }\end{array}$} & 5060.057 & 668.622 & & 7.568 & .000 & 3603.254 & 6516.860 \\
\hline & & $\begin{array}{l}\text { The number of } \\
\text { snowy days }\end{array}$ & & 1980.171 & 545.928 & .723 & 3.627 & .003 & 790.697 & 3169.646 \\
\hline \multirow{2}{*}{ January } & \multirow{2}{*}{1} & (Constant) & \multirow{2}{*}{$\begin{array}{l}\text { The number } \\
\text { of domestic } \\
\text { tourists }\end{array}$} & 16786.273 & 2557.422 & & 6.564 & .000 & 11214.131 & 22358.416 \\
\hline & & $\begin{array}{l}\text { The number of } \\
\text { snowy days }\end{array}$ & & -333.188 & 143.558 & -.557 & -2.321 & .039 & -645.974 & -20.401 \\
\hline \multirow{2}{*}{ March } & \multirow[b]{2}{*}{1} & (Constant) & \multirow{2}{*}{$\begin{array}{l}\text { The number } \\
\text { of domestic } \\
\text { tourists }\end{array}$} & 8141.594 & 1038.221 & & 7.842 & .000 & 5879.505 & 10403.683 \\
\hline & & $\begin{array}{l}\text { The number of } \\
\text { snowy days }\end{array}$ & & 160.552 & 69.940 & .552 & 2.296 & .041 & 8.165 & 312.938 \\
\hline \multirow{2}{*}{ June } & & (Constant) & The number & 4815.857 & 671.132 & & 7.176 & .000 & 3353.587 & 6278.128 \\
\hline & 1 & $\begin{array}{l}\text { The number of } \\
\text { snowy days }\end{array}$ & $\begin{array}{l}\text { of domestic } \\
\text { tourists }\end{array}$ & 1932.429 & 547.977 & .713 & 3.526 & .004 & 738.490 & 3126.368 \\
\hline & & (Constant) & The number & 244.200 & 22.955 & & 10.638 & .000 & 194.185 & 294.215 \\
\hline June & 1 & $\begin{array}{l}\text { The number of } \\
\text { snowy days }\end{array}$ & $\begin{array}{l}\text { of foreign } \\
\text { tourists }\end{array}$ & 47.743 & 18.743 & .592 & 2.547 & .026 & 6.906 & 88.580 \\
\hline
\end{tabular}

season. This does not refer to foreign tourists' arrivals to Kopaonik, as they mainly come at the height of tourist season: November to February (Table 2).

\section{Analysis of the impact of the number of snowy days on the tourist traffic at Zlatibor}

The results show that the number of snowy days in March on Zlatibor mountain negatively influences the total number of tourists and their overnight stays, as well as the number of domestic tourists. The number of snowy days in December, however, has a positive effect on the total number of overnight stays of domestic tourists. This analysis shows the results which are totally opposite of those obtained for Kopaonik mountain. This can be explained by the fact that Zlatibor is the mountain which offer is more directed to excursions and recreation in the spring. This is why it is visited by a higher number of tourists when the mean monthly temperatures are higher. In comparison to Kopaonik mountain, it attracts different segments of tourists - school excursions and recreational visitors more than typical ski tourists (Table 3).

\section{Analysis of the influence of the mean monthly temperature on the tourist traffic on Zlatibor}

From Table 4, it is evident that the mean monthly temperature during the year affects the tourist traffic on Zlatibor. In March, it positively affects the total num- 
Table 2. Results of regression analysis - influence of the mean monthly temperature on the tourist traffic at Kopaonik

\begin{tabular}{|c|c|c|c|c|c|c|c|}
\hline \multirow{2}{*}{\multicolumn{2}{|c|}{ Month }} & \multirow[t]{2}{*}{ Dependent Variable } & \multicolumn{2}{|c|}{ Unstandardized Coefficients } & \multirow{2}{*}{$\begin{array}{c}\text { Standardized } \\
\text { Coefficients }\end{array}$} & \multirow[t]{2}{*}{$\mathrm{t}$} & \multirow[t]{2}{*}{ Sig. } \\
\hline & & & B & Std. Error & & & \\
\hline \multirow{2}{*}{ August } & (Constant) & \multirow{2}{*}{$\begin{array}{l}\text { The total number of } \\
\text { tourists }\end{array}$} & 9460.869 & 2535.968 & & 3.731 & .003 \\
\hline & $\begin{array}{l}\text { The Mean monthly } \\
\text { temperature in Kopaonik }\end{array}$ & & -372.218 & 176.926 & -.519 & -2.104 & .057 \\
\hline \multirow{2}{*}{ March } & (Constant) & \multirow{2}{*}{$\begin{array}{l}\text { The number of } \\
\text { domestic tourists }\end{array}$} & 10098.458 & 367.708 & & 27.463 & .000 \\
\hline & $\begin{array}{l}\text { The Mean monthly } \\
\text { temperature in Kopaonik }\end{array}$ & & -308.948 & 146.291 & -.521 & -2.112 & .046 \\
\hline \multirow{2}{*}{ March } & (Constant) & \multirow{2}{*}{$\begin{array}{l}\text { The number of } \\
\text { domestic overnight } \\
\text { stays }\end{array}$} & 48395.431 & 2090.301 & & 23.152 & .000 \\
\hline & $\begin{array}{l}\text { The Mean monthly } \\
\text { temperature in Kopaonik }\end{array}$ & & -2247.588 & 831.618 & -.615 & -2.703 & .019 \\
\hline
\end{tabular}

Table 3. Results of regression analysis - influence of the number of snowy days on the tourist traffic on Zlatibor

\begin{tabular}{|c|c|c|c|c|c|c|c|c|c|c|}
\hline \multirow{2}{*}{ Month } & \multirow{2}{*}{\multicolumn{2}{|c|}{ Model }} & \multirow{2}{*}{$\begin{array}{l}\text { Dependent } \\
\text { variable }\end{array}$} & \multicolumn{2}{|c|}{$\begin{array}{l}\text { Unstandardized } \\
\text { Coefficients }\end{array}$} & \multirow{2}{*}{$\begin{array}{c}\text { Standardized } \\
\text { Coefficients } \\
\text { Beta }\end{array}$} & \multirow{2}{*}{$\mathrm{t}$} & \multirow{2}{*}{ Sig. } & \multicolumn{2}{|c|}{$\begin{array}{l}95.0 \% \text { Confidence } \\
\text { Interval for B }\end{array}$} \\
\hline & & & & B & Std. Error & & & & $\begin{array}{l}\text { Lower } \\
\text { Bound }\end{array}$ & $\begin{array}{l}\text { Upper } \\
\text { Bound }\end{array}$ \\
\hline \multirow{2}{*}{ March } & \multirow{2}{*}{1} & (Constant) & \multirow{2}{*}{$\begin{array}{l}\text { The total } \\
\text { number of } \\
\text { overnight } \\
\text { stays }\end{array}$} & 31802.214 & 3070.304 & & 10.358 & .000 & 31802.214 & 3070.304 \\
\hline & & $\begin{array}{l}\text { The number of } \\
\text { snowy days }\end{array}$ & & -400.661 & 160.770 & -.584 & -2.492 & .028 & -400.661 & 160.770 \\
\hline \multirow[b]{2}{*}{ December } & \multirow[b]{2}{*}{1} & (Constant) & \multirow{2}{*}{$\begin{array}{l}\text { The total } \\
\text { number of } \\
\text { overnight } \\
\text { stays }\end{array}$} & 7407.417 & 5296.790 & & 1.398 & .187 & 7407.417 & 5296.790 \\
\hline & & $\begin{array}{l}\text { The number of } \\
\text { snowy days }\end{array}$ & & 665.405 & 228.970 & .643 & 2.906 & .013 & 665.405 & 228.970 \\
\hline \multirow{2}{*}{ December } & \multirow[b]{2}{*}{1} & (Constant) & \multirow{2}{*}{$\begin{array}{l}\text { The number } \\
\text { of domestic } \\
\text { tourists }\end{array}$} & 6001.156 & 5321.191 & & 1.128 & .281 & 6001.156 & 5321.191 \\
\hline & & $\begin{array}{l}\text { The number of } \\
\text { snowy days }\end{array}$ & & 630.649 & 230.024 & .621 & 2.742 & .018 & 630.649 & 230.024 \\
\hline \multirow{2}{*}{ March } & \multirow[b]{2}{*}{1} & (Constant) & \multirow{2}{*}{$\begin{array}{l}\text { The total } \\
\text { number of } \\
\text { tourists }\end{array}$} & 6927.765 & 628.837 & & 11.017 & .000 & 6927.765 & 628.837 \\
\hline & & $\begin{array}{l}\text { The number of } \\
\text { snowy days }\end{array}$ & & -75.800 & 32.928 & -.553 & -2.302 & .040 & -75.800 & 32.928 \\
\hline \multirow[b]{2}{*}{ March } & \multirow[b]{2}{*}{1} & (Constant) & \multirow{2}{*}{$\begin{array}{l}\text { The number } \\
\text { of domestic } \\
\text { tourists }\end{array}$} & 6153.743 & 509.987 & & 12.066 & .000 & 6153.743 & 509.987 \\
\hline & & $\begin{array}{l}\text { The number of } \\
\text { snowy days }\end{array}$ & & -67.473 & 26.704 & -.589 & -2.527 & .027 & -67.473 & 26.704 \\
\hline
\end{tabular}

ber of overnight stays and domestic overnight stays, which coincides with the results of the analysis between the number of snowy days and tourist traffic. The analysis showed different results in comparison to Kopaonik, where lower temperatures extend the tourist season. In December, the mean monthly temperatures negatively affect the total but also the number of domestic tourists, because it is the pick of tourist season, and tourists seek places with lower temperatures. In August, however, there is a positive impact on the number of domestic tourists. These results are also different in comparison to Kopaonik where higher temperatures in August negatively affect the number of tourist arrivals. The higher number of tourists on Zlatibor in August can be explained by the fact tourists in city centers seek salvation from the summer heat at the mountains. The results of regression analysis are logically connected with the results of regression with the number of snowy days as an independent variable (Table 4). 
Table 4. Results of regression analysis - influence of the mean monthly temperature on the tourist traffic at Zlatibor

\begin{tabular}{|c|c|c|c|c|c|c|c|c|}
\hline \multirow[t]{2}{*}{ Month } & \multirow{2}{*}{\multicolumn{2}{|c|}{ Model }} & \multirow[t]{2}{*}{ Dependent variable } & \multicolumn{2}{|c|}{ Unstandardized Coefficients } & \multirow{2}{*}{$\begin{array}{c}\text { Standardized } \\
\text { Coefficients } \\
\text { Beta } \\
\end{array}$} & \multirow[t]{2}{*}{$\mathrm{t}$} & \multirow[t]{2}{*}{ Sig. } \\
\hline & & & & B & Std. Error & & & \\
\hline \multirow[b]{2}{*}{ March } & \multirow[b]{2}{*}{1} & (Constant) & \multirow{2}{*}{$\begin{array}{l}\text { The total number of } \\
\text { overnight stays }\end{array}$} & 18611.027 & 2905.630 & & 6.405 & .000 \\
\hline & & $\begin{array}{l}\text { The mean monthly } \\
\text { temperature on } \\
\text { Zlatibor }\end{array}$ & & 1923.610 & 794.988 & .573 & 2.420 & .032 \\
\hline \multirow[b]{2}{*}{ December } & \multirow[b]{2}{*}{1} & (Constant) & \multirow{2}{*}{$\begin{array}{l}\text { The total number of } \\
\text { overnight stays }\end{array}$} & 19830.507 & 1437.117 & & 13.799 & .000 \\
\hline & & $\begin{array}{l}\text { The mean monthly } \\
\text { temperature on } \\
\text { Zlatibor }\end{array}$ & & -2349.926 & 708.693 & -.691 & -3.316 & .006 \\
\hline \multirow[b]{2}{*}{ March } & \multirow[b]{2}{*}{1} & (Constant) & \multirow{2}{*}{$\begin{array}{l}\text { The number of } \\
\text { domestic overnight } \\
\text { stays }\end{array}$} & 17129.675 & 2929.405 & & 5.847 & .000 \\
\hline & & $\begin{array}{l}\text { The mean monthly } \\
\text { temperature on } \\
\text { Zlatibor }\end{array}$ & & 1916.109 & 801.492 & .568 & 2.391 & .034 \\
\hline \multirow[b]{2}{*}{ December } & \multirow[b]{2}{*}{1} & (Constant) & \multirow{2}{*}{$\begin{array}{l}\text { The number of } \\
\text { domestic overnight } \\
\text { stays }\end{array}$} & 17434.690 & 1260.658 & & 13.830 & .000 \\
\hline & & $\begin{array}{l}\text { The mean monthly } \\
\text { temperature in } \\
\text { Zlatibor }\end{array}$ & & -2547.272 & 621.675 & -.764 & -4.097 & .001 \\
\hline \multirow{2}{*}{ August } & \multirow[b]{2}{*}{1} & (Constant) & \multirow{2}{*}{$\begin{array}{l}\text { The number of } \\
\text { domestic tourists }\end{array}$} & 1067.172 & 2271.323 & & .470 & .647 \\
\hline & & $\begin{array}{l}\text { The mean monthly } \\
\text { temperature in } \\
\text { Zlatibor }\end{array}$ & & 396.708 & 123.421 & .680 & 3.214 & .007 \\
\hline
\end{tabular}

\section{Conclusion}

Kopaonik and Zlatibor are distinguished by their positions, as well as with attractive and rich tourist offer. Basic tourist attributes are natural values such as relief, climate, hydrological values, flora and fauna, as well as numerous anthropogenic values. Tourism has a long tradition in these mountains, and also, they are the most visited mountains in Serbia. The increase or decrease in the number of tourists during the evaluating period is inevitable influence by the relevant climatic parameters, such as average monthly air temperature and number of snowy days. Having in mind that Zlatibor is a mountain attractive for short visits and excursions as well as the center of health tourism, tourist traffic is reasonably the highest during the summer and spring months. This trend corresponds to the minimum number of snow days and higher air temperatures. This explains the finding that the smaller number of snow days and higher air temperature affect the increase of the number of tourists in March. On the other hand, Kopaonik is the ski resort, popular not only in Serbia but also in this part of Europe. The increase in temperature and decrease in snowfall in March resulted in a decrease in the number of tourists coming to Kopaonik. The longer retention of snow cover is the major reason for the extension of the tourist season. Recently, an increasing number of tourists was recorded during the summer months, which is caused by a lower air temperature. In the analyzed period, there was an increase in the number of tourists on Zlatibor, while on Kopaonik recorded a significant decline. Results indicate that Zlatibor and Kopaonik, as very different types of mountains, attract different segments of tourists. The results obtained, especially on seasonality of visit, can be used for design and improvement of tourist offer in order to extend the tourist season in both analyzed mountains (Kopaonik - for the extension of the winter season in the case of reducing the number of days with snow, and Zlatibor - to attract tourists during the winter months). How climate change and the selected parameters in the future will affect the tourist visits in these mountains, may be the subject of the future research. Also, by monitoring the detailed parameters of contemporary climate variability and predictions on the regional level, the strategic approach for planning and adaptation of tourist destinations in the Republic of Serbia would certainly improve. Utilization of Tourism Climatic Index (TCI) in future studies (as part of the general methods used for the quantification of climate conditions for tour- 
ism industry), could be used for planning of tourist activities in both, developed and undeveloped tourist centers of Serbia, with exception of those highly dependent on winter tourism. In this way direct information can be sent to tourists and stakeholders in decision-making activities throughout the year.

\section{References}

Armstrong, J. S. 2012. Illusions in Regression Analysis. International Journal of Forecasting (forthcoming) 28(3), 689-694.

Basarin, B., Kržič, A., Lazić, L., Lukić, T., Đorđević, J., Janićijević Petrović, B., Ćopić, S., Matić, D., Hrnjak, I., Matzarakis, A. 2014. Evaluation of bioclimate conditions in two special nature reserves in Vojvodina (northern Serbia). Carpathian Journal of Earth and Environmental Sciences 9(4), 93-108.

Bojović, G., Plavša, J. 2010. Tourist Turnover in the Spas of the Kopaonik Piedmont. Researches Review of the Department of Geography, Tourism and Hotel Management 39, 123-140. (in Serbian with English summary)

Bojović, G., Plavša, J. 2011. Swot Analysis of Tourism on Kopaonik and the Spas of its Piedmont. Turizam 15(3), 109-118.

Bursać, M. 1991. Natural Conditions for Agriculture and Forest Economy Development in a Winder Kopaonik Region. Journal of the Geographical Institute "Jovan Cvijić" SASA 43, 137-149. (in Serbian with English summary)

Bučić, A., Cimbaljević, M., Janković, V. 2015. Possibilities for the Development of Congress Tourism on Zlatibor Mountain. Researches Review of the Department of Geography, Tourism and Hotel Management 44(1), 83-93.

Dinca, A. I., Surugiu, C., Surugiu, M.R., Frent, C. 2014. Stakeholder perspectives on climate change effects on tourism activities in the northern Romanian Carpathians: Vatra Dornei resort case study. $\mathrm{Hu}$ man Geographies 8(1), 27-41.

Ducić, V., Radovanović, M. 2005. Climate of Serbia. Zavod za udžbenike i nastavna sredstva, Belgrade, 212 pp. (in Serbian)

Đurić, A., Pavlović, J. 2005. Zlatibor Mountain, Tourist organization of Zlatibor, Zlatibor.

Đurović, P., Menković, Lj. 2008. The Duboka Piracy. Journal of the Geographical Institute "Jovan Cvijić" SASA $58,17-27$.

Elsasser, H., Messerli, P. 2001. The vulnerability of the snow industry in the Swiss Alps. Mountain research and development 21(4), 335-339.

Freitas, de C. R. 2003. Tourism Climatology: Evaluating Environmental Information for Decision Making and Business Planning in the Recreation and
Tourism Sector. International Journal of Biometeorology 48(1), 45-54.

Giannakopoulos, C., Kostopoulou, E., Varotsos, K. V., Tziotziou, K., Plitharas, A. 2011. An Integrated Assessment of Climate Change Impacts for Greece in the Near Future. Regional Environmental Change $11(4), 829-843$.

Gómez Martín, M. B. 2005. Weather, Climate and Tourism A Geographical Perspective. Annals of Tourism Research 32(3), 571-591.

Gössling, S., Bredberg, M., Randow, A., Sandström, E., Svensson, P. 2006. Tourist Perceptions of Climate Change: A study of International Tourists in Zanzibar. Current issues in Tourism 9(4-5), 419-435.

Hein, L., Metzger, M. J., Moreno, A. 2009. Potential impacts of climate change on tourism; a case study for Spain. Current Opinion in Environmental Sustainability 1, 2, 170-178.

Ivanović, M. 2007. Modern characteristics of tourism on Zlatibor. Turizam 11, 167-170. (in Serbian with English summary)

IPCC. 2013. Climate Change 2013: The Physical Science Basis. Contribution of Working Group I to the Fifth Assessment Report of the Intergovernmental Panel on Climate Change [Stocker, T.F., D. Qin, G.- K. Plattner, M. Tignor, S.K. Allen, J. Boschung, A. Nauels, Y. Xia, V. Bex and P.M. Midgley (eds.)]. Cambridge University Press, Cambridge, United Kingdom and New York, NY, USA, 1535 pp.

Joksimović, M., Gajić, M., Golić, R. 2013. Tourism climatic index in the valorisation of climate in tourist centers of Montenegro. Bulletin of the Serbian Geographical Society 43, 15-26.

Jovanović, D., Govedarica, M., Sabo, F., Bugarinović, Ž., Novović, O., Beker, T., Lauter, M. 2015. Land Cover change detection by using Remote Sensing A Case Study of Zlatibor (Serbia). Geographica Pannonica 19(4), 162-173.

Jovičić, Ž. 1992. Kopaonik - protection and development of tourism. Journal of the Geographical Institute "Jovan Cvijic" SASA 44-45, 153-210. (in Serbian with English summary)

Kadović, R., Belanović, S., Knežević, M., Belojica, J., Knežević, J. 2009. Analysis of forest soil acidification processes in the area of NP „Kopaonik”. Bulletin of the Faculty of Forestry 100, 95-110. (in Serbian with English summary)

León, C. J., Araña, J. E. 2016. The Economic Valuation of Climate Change Policies in Tourism Impact of Joint Valuation, Emotions, and Information. Journal of Travel Research 55(3), 283-298.

Marković, V. 2008. Tourist effect of the hunter meeting on Zlatibor. Researches Review of the Department of Geography, Tourism and Hotel Management 37, 146152. (in Serbian with English summary) 
Matzarakis, A. 2006. Weather- and Climate-Related Information for Tourism. Tourism and Hospitality Planning \& Development 3(2), 99-115.

Mieczkowski, Z. 1985. The tourism climatic index: a method of evaluating world climates for tourism. The Canadian Geographer/Le Géographe Canadien 29(3), 220-233.

Pavlović, S., Jovanović, B. 2009. Complementarity of eco and ethno tourism on examples of Zlatibor's villages. Collection of Papers - Faculty of Geography at the University of Belgrade 57, 165-180. (in Serbian with English summary)

Plavša, J., Romelić, J., Vuksanović, D. Lj. 2009. Active Holiday in Mt. Zlatibor County. Turizam 13, 1, 2844.

Romelić, J., Plavša, J., Đurović, D. 2009. The evaluation of tourist events on Zlatibor mountain. Researches Review of the Department of Geography, Tourism and Hotel Management 38, 158-183. (in Serbian with English summary)

Scott, D., McBoyle, G., Schwartzentruber, M. 2004. Climate change and the distribution of climatic resources for tourism in North America. Climate research 27(2), 105-117.

Stanković, S., Cirković, S. 2002. The number of tourists on Zlatibor. Bulletin of the Serbian Geographical Society 82(1), 31-44. (in Serbian with English summary)

Stojsavljević, R., Savić, S., Milošević, D., Stojanov, S., Leščešen, I., Majstorović, V. 2013. Interpolation and
Extrapolation of Precipitation Quantities in Serbia. European Researcher 55(7-2), 1980-1986.

Surugiu, C., Dincă, A. I., Micu, D. 2010. Tourism Destinations Vulnerable to Climate Changes: An Econometric Approach on Predeal Resort. Petroleum-Gas University of Ploiesti Bulletin, Economic Sciences Series 62(1), 111-120.

Surugiu, C., Surugiu, M. R., Frent, C., Breda, Z. 2011. Effects of climate change on Romanian mountain tourism: are they positive or mostly negative? European Journal of Tourism, Hospitality and Recreation 2(1), 42-71.

Šabić, D., Vujadinović, S., Milinčić, M., Golić, R., Stojković, S., Joksimović, M., Filipović, D., Šećerov, V., Dimitrijević, D. 2012. The Impact of FDI on the Transitional Economy in Serbia - Changes and Challenges. Acta Polytechnica Hungarica 9(3), 6584.

Vujević, P. 1961. Contributions to bioclimatology of area Kopaonik mountain. Journal of the Geographical Institute "Jovan Cvijić" SASA 18, 1-91. (in Serbian with French summary)

Živanović, S. 2015. Evaluating the impact of climate on forest vulnerability to fires. Acta Agriculturae Serbica 20, 17-28.

Wilks, D. S. 2006. Statistical methods in the atmospheric sciences - Second Edition. International Geophysics Series, Department of Earth and Atmospheric Sciences Cornell University, New York, $649 \mathrm{pp}$. 